\title{
Erratum to: In Vitro Methods for In Vivo Quantitation of PET and SPECT Imaging Probes: Autoradiography and Gamma Counting
}

F. Kiessling and B.J. Pichler (eds.), Small Animal Imaging,

(C) Springer-Verlag Berlin Heidelberg 2011

DOI: 10.1007/978-3-642-12945-2_24

This book chapter has been written by two authors but unfortunately the name of Cinthia V. Pastuskovas was missing in the first version.

David Stout and Cinthia V. Pastuskovas

D.Stout

Preclinical Imaging Center, UCLA Crump Institute

For Molecular Imaging, 570 Westwood Plaza,

CMNSI room 2151, Los Angeles, CA 90095 USA

e-mail: d.stout@mednet.ucla.edu

Cinthia V. Pastuskovas

Pharmacokinetic and Pharmacodymic Sciences, Genentech, Inc.

640 E. Grand Ave. South San Francisco, California, CA 94080 USA

e-mail: pastuskovas.cinthia@gene.com

The online version of the original chapter can be found at DOI: 10.1007/978-3-642-12945-2-24 